\title{
NOTES
}

\section{IF WORDS COULD KILL: CAN THE GOVERNMENT REGULATE $A N Y$ ONLINE SPEECH?}

\section{Laura Pontzer}

\section{INTRODUCTION}

From the inception of American jurisprudence, an individual's right to freedom of speech and expression guaranteed by the First Amendment to the United States Constitution ${ }^{1}$ has been given some of the strongest protection available. ${ }^{2}$ The most celebrated legal minds in American history have consistently advocated the necessity of an open and honest exchange of ideas as fundamental to democratic society, ${ }^{3}$ even when the ideas expressed may be

* Laura Pontzer earned a J.D. from the University of Pittsburgh School of Law in 2011, and she holds a B.A. in International Development Studies from McGill University, 2006. She is very grateful to her family and friends, without whose unfailing love and support she would have given up on many things, many times. Special thanks to Dr. Mary Pontzer, her first and favorite teacher, for always helping her find her way. She can be reached at laura.pontzer@gmail.com.

1. U.S. CONST. amend. I ("Congress shall make no law . . . abridging the freedom of speech, or of the press.").

2. See, e.g., Perry Educ. Ass’n v. Perry Local Educators’ Ass'n, 460 U.S. 37, 45 (1983) (“[T]he rights of the state to limit expressive activity are sharply circumscribed"); see also Carey v. Brown, 447 U.S. 455, 461 (1980) (holding that statutes proscribing activity protected under the First Amendment must be "finely tailored to serve substantial state interests.").

3. Abrams v. United States, 250 U.S. 616, 630 (1919) (Holmes, J. dissenting) ("[T]he best test of truth is the power of the thought to get itself accepted in the competition of the market, and that truth is the only ground upon which their wishes safely can be carried out. That at any rate is the theory of our Constitution.”); De Jonge v. Oregon, 299 U.S. 353, 364 (1937) (Hughes, C.J.) (“The First Amendment of 
unpopular or of little value. ${ }^{4}$ Nonetheless, it is equally well-established that not all speech is protected, particularly where the speech in question poses a threat to public order. ${ }^{5}$ Although First Amendment law continues to evolve, the media available to Americans wishing to express their ideas seem to be evolving exponentially faster, particularly in the forum provided by the Internet. ${ }^{6}$ Indeed, the vast expansion and availability of Internet media seem to continually outstrip the much more gradual evolution of the law, not only in the United States but worldwide. ${ }^{7}$

Unfortunately, the exchange of ideas over the Internet has a dark side that the framers of the First Amendment could not possibly have anticipated: in addition to sharing ideas about politics, current events, and other comparatively benign topics, a small but nevertheless troubling group of Internet users have acutely suffered as a result of the activity of fellow users enjoying the shield of anonymity the Internet uniquely provides. ${ }^{8}$ Although

the Federal Constitution expressly guarantees that right against abridgment by Congress.... [Such right] cannot be denied without violating those fundamental principles of liberty and justice which lie at the base of all civil and political institutions").

4. United States v. Playboy Entm't Group, Inc., 529 U.S. 803, 826 (2000) (noting that expression of distasteful speech is not necessarily unprotected; speech need not be "very important" to be protected unless patently offensive or specifically appealing to the prurient interest); see also Ashcroft v. Free Speech Coalition, 535 U.S. 234, 245-46 (2002).

5. Abrams, 250 U.S. at 628 (Holmes, J., dissenting) ("[T]he United States constitutionally may punish speech" that poses "clear and present danger" of unlawful activity); Chaplinsky v. New Hampshire, 315 U.S. 568, 571-72 (1942) ("There are certain well-defined and narrowly limited classes of speech, the prevention and punishment of which has never been thought to raise any Constitutional problem") (footnote omitted); Dennis v. United States, 341 U.S. 494, 510 (1951) (rejecting First Amendment challenge under a variation of "clear and present danger" test earlier articulated by Judge Learned Hand); Roth v. United States, 354 U.S. 476, 482 (1957) (acknowledging that guarantees of First Amendment have never been absolute).

6. Reno v. ACLU, 521 U.S. 844, 850 (1997) ("[T]he Internet is 'a unique . . medium of worldwide human communication [that] . . . has experienced "extraordinary growth.").

7. See, e.g., Erin Anderssen, Depressed? Maybe You'd Better Stay off the Web, GLOBE \& MAIL (Toronto), Feb. 28, 2009, at F3, available at http://www.theglobeandmail.com/news/technology/ article973486.ece (reporting that the logistics of policing Internet activity are difficult politically and legally; recent efforts to restrict use of pro-suicide sites in Australia and Japan "have largely failed."); Adrian McCoy, Cyberspace Becoming a Legal Battleground, Pittsburgh Post-Gazette, July 5, 2008, at A1, available at http://www.post-gazette.com/pg/08187/894946-96.stm (suggesting that law has not kept up with pervasive use and rapid expansion of Internet; "the legal principles governing conduct . . . in cyberspace are still in a state of flux"); Melissa Healy, My Pal, My Bully, L.A. TiMEs, Jan. 26, 2009, at F1.

8. Anderssen, supra note 7 (describing multiple reports of teen suicides after use of pro-suicide chat rooms, including 19-year-old Florida man who committed suicide while viewers watched live on website); see also Healy, supra note 7 (noting that teens most frequently face bullying and harassment over the Internet); Robin Eveleigh \& Tanith Carey, Your Life: I Blame Suicide Websites for My Beautiful Imogen's Death, MIRROR (UK), Dec. 6, 2008, at 38 (observing that suicide websites are readily available and easy to use); US Web Suicide Suspect Ends Up in a Prison Cell, Lancashire Evening Post (UK), 
some legislators have proposed measures meant to curtail the problems caused by "cyber-bullying," experts are unconvinced that such legislation could be constitutional. ${ }^{10}$ Considering in combination the destructive potential of some Internet speech, the foundational principles of First Amendment law, and what little precedent there is for regulating speech on the Internet, it is apparent that some sort of mitigating action both should and could be taken.

This Note will explore the problems posed by two relatively new Internet phenomena, cyber-bullying and suicide chat rooms, followed by an analysis of legal efforts to curtail negative effects of certain speech in both forums. I will then discuss the First Amendment implications of those efforts, followed by an overview of potential remedies at both the government and private levels. Ultimately I conclude that cooperation between the public and private sectors is likely necessary to effectively develop a properly-tailored approach to protect the otherwise dangerously vulnerable victims of these unique and relatively novel threats.

\section{The Problem with the Internet}

The Internet offers virtually limitless opportunities to do almost anything in the convenience and privacy of the home. Many Americans today, especially the younger generations, would feel lost and most likely insecure without it. ${ }^{11}$ It is safe to assume that the framers of the First Amendment,

Feb. 17, 2005 (reporting on man charged with solicitation to commit murder "after allegedly attracting vulnerable people to take part in a mass suicide ... through his suicide website, "Suicide Ideology"), litigated sub nom. State v. Krein, 188 P.3d 467 (Or. App. 2008) (finding defendant guilty except for insanity; reversing conviction and remanding case due to defective jury instructions) [hereinafter US Web Suicide Suspect]; Paul Walsh, Nurse Involved in Suicide Chats Loses License, Star Tribune (MinNEAPOLIS), Oct. 15, 2009, at 01A (telling of nurse with "suicide fetish" possibly responsible for deaths of multiple people, adult and teen, American and foreign, not charged because of jurisdictional and constitutional concerns).

9. See, e.g., Tresa Baldas, “Cyber-Bullying” Grows \& So Do Lawsuits, 190 N.J. L.J. 973, 973 (2007) (arguing that school districts are uncertain how to handle cyber-bullying, which has resulted in multiple suicides, and that courts have been divided on whether states may regulate cyber-bullying despite various legislative efforts to do so).

10. Victoria Kim, Judge Backs Student's First Amendment Rights, L.A. Times, Dec. 14, 2009 (reporting on judge who held that school violated First Amendment rights of student by suspending her for posting online a video taunting another student); Sean Rose, Federal Cyber Bully Bill Gets New Life, ST. Louis Post-Dispatch, May 5, 2009, at A1 (noting that leading expert in field of First Amendment law declares proposed federal anti-cyber-bullying bill unconstitutionally vague, and that Internet rights group says criminal penalties threatened by bill would violate civil liberties).

11. Sarah Kershaw, Hooked on the Web: Help Is on the Way, N.Y. TimEs, Dec. 1, 2005, at G1, available at $\mathrm{http}: / / \mathrm{www} . n y t i m e s . c o m / 2005 / 12 / 01 /$ fashion/thursdaystyles/01addict.html?pagewanted=print. 
writing in the late Eighteenth Century, could not have conceptualized the substantial amount of harmful public speech that is expressed today, often carelessly and even recklessly, in the widely available forum of the Internet. ${ }^{12}$ Nonetheless, as such speech has emerged the trend in American jurisprudence has been to extend First Amendment protections just as liberally to that speech as has been given to expression over other media. ${ }^{13}$ While Internet speech undoubtedly merits some protection, not all such speech is the same, particularly speech that poses a legitimate threat to public health. ${ }^{14}$

\section{A. Cyber-Bullying}

Even before technology was as commonplace as it is today, legislators expressed concern over the new potential dangers to children created by the rise of "virtual" pornography. ${ }^{15}$ Shortly thereafter, Congress attempted to enact legislation in Title V of the Telecommunications Act of 1996 to regulate the distribution of child pornography over the internet. ${ }^{16}$ Even though the Supreme Court struck down that legislation because it prohibited substantially more expression than was necessary to serve the child-protection rationale, ${ }^{17}$ the Court noted the "legitimacy and importance of the congressional goal of protecting children from harmful materials." ${ }^{\prime 18}$ Indeed, the Court has recently

12. Donna Winchester, Cyberbullying on the Rise, St. Petersburg Times, Mar. 3, 2009, at 1B, available at $\mathrm{http}: / / \mathrm{www}$. tampabay.com/news/education/k12/article980638.ece ("[K]ids are more likely to be cruel when they don't have to witness firsthand the reaction of the one they're tormenting"); Walsh, supra note 8 (noting the alarming rise of "suicide chat rooms, where people from across the globe meet online to talk about suicide and how to do it"); Eveleigh \& Carey, supra note 8 (quoting mother of a 13-year-old who committed suicide after using suicide chat rooms as saying "the information was so explicit and available ... [it] came in to our home and we were defenceless.").

13. Reno, 521 U.S. at 850; Layshock v. Hermitage Valley Sch. Dist., 593 F.3d 249, 253 (3d Cir. 2010) (upholding First Amendment claims of students against school districts that took disciplinary actions based on students' online posts), reh'g en banc granted, opinion vacated Apr. 9, 2010; see also Dwyer v. OceanPort Sch, Dist., No. 03-CV-6005 (D.N.J. 2005) (same), available at http://www.citmedialaw.org/ sites/citmedialaw.org/files/DwyerOpinion.pdf.; Latour v. Riverside Beaver Sch. Dist, 2005 WL 2106562, *1-3 (W.D. Pa. Aug. 24, 2005).

14. Baldas, supra note 9 (discussing multiple suicides attributed in part to cyber-bullying); Anderssen, supra note 7 (reporting on suicides attributed to both cyber-bullying and availability of advice and encouragement in suicide chat rooms); see also Emma Harris, Parents Call for Ban on Suicide Chatrooms, Black pool GazetTe (UK), Apr. 2, 2009, 2009 WLNR 11551690.

15. Ashcroft, 535 U.S. at 241-42 ("Pedophiles might use such material to encourage children to participate in sexual activity ... [or to] whet their own sexual appetites.").

16. Reno, 521 U.S. at $849-54$ (tracking the development of, ease of access to, and availability of sexually explicit material on the Internet).

17. Ashcroft, 535 U.S. at $249-51,254$.

18. Reno, 521 U.S. at 849. 
upheld similar legislation against a First Amendment challenge. ${ }^{19}$ In summing up, the Court noted:

Child pornography harms and debases the most defenseless of our citizens. Both the State and Federal Governments have sought to suppress it for many years, only to find it proliferating through the new medium of the Internet. This Court held unconstitutional Congress's previous attempt to meet this new threat, and Congress responded with a carefully crafted attempt to eliminate the First Amendment problems we identified. As far as the provision at issue in this case is concerned, that effort was successful. ${ }^{20}$

The First Amendment hurdle may have only recently been cleared in the prohibition of child pornography, but First Amendment law as it relates to pornography more generally is a relatively well-established area dating back to obscenity cases that first came to the Supreme Court in the late $1950 \mathrm{~s} .{ }^{21}$ In those cases, the Court concluded that obscenity was categorically excluded from First Amendment protection. ${ }^{22}$ The Court subsequently held that the government had a sufficiently strong interest in regulating material harmful to children to justify upholding a content-based statutory prohibition on producing and distributing any material representing sexual conduct by a child under the age of sixteen. ${ }^{23}$

Modern First Amendment law unequivocally denies First Amendment protection to child pornography. As a result, legislators have become adept at regulating child pornography without running afoul of the Constitution. ${ }^{24}$ In contrast, the practice known as "cyber-bullying" is so novel that in addition to the lack of authoritative precedent on the subject, ${ }^{25}$ no current legislator or judge has much firsthand knowledge of the subject. ${ }^{26}$

19. United States v. Williams, 553 U.S. 285, 288 (2008).

20. Id. at 307 .

21. Roth v. United States, 354 U.S. 476, 479 (1957), modified by Memoirs v. Mass., 383 U.S. 413, 418 (1966) (plurality opinion).

22. Id. at 486 .

23. New York v. Ferber, 458 U.S. 747, 756 (1982) ("[W]e are persuaded that the States are entitled to greater leeway in the regulation of pornographic depictions of children.").

24. See Williams, 553 U.S. at 306-07.

25. Kim, supra note 10 ('[W]ith teens' social lives moving increasingly to cyberspace, where what previously might have been a private bickering is [made public] . . . school officials find themselves on unfamiliar grounds. . . [T]he murkiness of this area of law and educational policy have led to legal challenges across the country.").

26. Rose, supra note 10 (quoting Rep. Sanchez, sponsor of the federal Cyberbullying Prevention Act, attributing "the bill's quiet death last year to the fact that cyber-bullying is a new concept to many members of Congress who have a dated view of bullying as an unfortunate part of growing up."); McCoy, supra note 7 ("“Cyber law' is instead being developed by judges who must do their best to fit legal disputes into preexisting legal frameworks."). 
Cyber-bullying can take many forms. Most often one or more individuals, usually under age eighteen, posts in a public online forum a message that in some way degrades, insults, or harasses another individual, typically a peer. ${ }^{27}$ The case that brought the phenomenon the most national attention was that of Lori Drew, a Missouri mother who pretended to be a teenage boy on the social networking site MySpace and harassed her daughter's friend Megan Meier to the point that Megan hanged herself in her home at the age of thirteen. ${ }^{28}$ Missouri prosecutors decided not to charge Ms. Drew because at the time no Missouri law covered Internet harassment, and the facts of the case did not fit the standard necessary to press criminal charges. ${ }^{29}$ A United States Attorney in Los Angeles, the jurisdiction where MySpace is headquartered, did take up the case and obtained a jury verdict against Ms. Drew, but only on misdemeanor charges. ${ }^{30}$ However, a California appellate judge has since thrown out Ms. Drew's conviction, stating that "if Drew is to be found guilty of illegally accessing computers, anyone who has ever violated the social networking site's terms of service would be guilty of a misdemeanor." ${ }^{31}$

Therein lies one of the problems with regulating cyber-bullying, namely that it is difficult to draw the line between what is harassment and what is merely offensive, but protected, speech. ${ }^{32}$ Experts note that the Internet, especially to younger generations, is "full of make believe" in that people feel more free to express themselves more outrageously than they otherwise would because of the lack of face-to-face interaction. ${ }^{33}$ Nonetheless, for the often young victims of cyber-bullying, the "expression" that constitutes cyberbullying not only lacks value but causes real and substantial harm. Like Megan Meier, other cyber-bullying victims have gone as far as committing suicide. ${ }^{34}$ Also troubling are the rising numbers of students unwilling to go to class, even to the point of dropping out of school, due to the pervasive and incessant nature of cyber-bullying. ${ }^{35}$ Overall the adverse effects of cyber-

27. McCoy, supra note 7.

28. Laura Bauer, Cyberbullying Case Brings Big Changes, Kansas City StaR (Mo.), May 25, 2009 , at A1.

29. Id.

30. Rose, supra note 10.

31. Tom McCarthy \& Scott Michaels, Lori Drew MySpace Suicide Hoax Conviction Thrown Out, ABC News (July 2, 2009), http://abcnews.go.com/TheLaw/story?id=7977226\&page=1.

32. James C. Goodale, Cyber-Bullying: First Amendment Community Holds Its Breath, 241 N.Y. L.J., Feb. 6, 2009, available at www.jamesgoodale.net/images/181.doc.

33. Bauer, supra note 28; Winchester, supra note 12; Goodale, supra note 32.

34. See, e.g., Winchester, supra note 12 (telling of 15-year-old Florida boy who killed himself in 2005 "after being harassed over the Internet.").

35. Kim, supra note 10; Winchester, supra note 12 (stating that cyber-bullying "generally originates 
bullying are undeniably tangible, and the pervasiveness and magnitude of the damage will likely only worsen as teens' Internet savvy continues to increase.

\section{B. "Suicide Chat Rooms"}

Another form of Internet speech, not completely unrelated to cyberbullying, is that of suicide chat. Easy-to-access "suicide chat rooms" provide a place where the curious, those seeking help or comfort, and outsider voyeurs can all go to discuss or find information about all aspects of committing suicide. ${ }^{36}$ While these sites may be helpful, particularly if directed by experts, the discussion that goes on in a suicide chat room may also reinforce a participant's or viewer's depression and validate suicidal thinking. ${ }^{37}$

In 2008, 1,500 people watched as Abraham Biggs, a nineteen-year-old Florida college student, killed himself by taking a fatal overdose of prescription medication. ${ }^{38}$ During Abraham Biggs suicide broadcast, various site users either encouraged or attempted to dissuade him, but none of them contacted authorities until after Abraham successfully overdosed. ${ }^{39}$ This scenario provides a horrific example of one of the main problems with Internet speech: Not everyone takes it seriously, and those who express a need for help in a given online forum may not only be ignored but, worse, may be encouraged to take their own lives. ${ }^{40}$

Although it is as yet uncommon for a suicide chat room user to take his or her life, the recent incidence of actual suicides among such users seems far too frequent. In 2004, nine strangers in Japan committed suicide as part of pacts planned when they met through suicide websites. ${ }^{41}$ Similarly, the British Parliament has undertaken legislation to regulate suicide chat after the suicides of multiple British teens who sought and received both instructional information and encouragement from online suicide chat, and who in at least

from home computers, [but] it almost always ends up on campus.").

36. Walsh, supra note 8; US Web Suicide Suspect, supra note 8; Mike Waites, Why an Obsession with the Internet is Linked to Depression, Yorkshire Post, Feb. 3, 2010, available at http:// www.yorkshirepost.co.uk/news/Why-an-obsession-with-the.6037347.jp; Harris, supra note 14; Anderssen, supra note 7.

37. Anderssen, supra note 7.

38. Laura Ingraham, The O'Reilly Factor: Unresolved Problem (Fox News television broadcast Nov. 24, 2008); see Rasha Madkour, Florida Teen Abraham Biggs Live-Streams His Suicide On Internet, The Huffington Post (Nov. 21, 2008, 09:51 PM), http://www.huffingtonpost.com/2008/11/21/floridateen-live-streams_n_145499.html.

39. Ingraham, supra note 38; Anderssen, supra note 7.

40. Anderssen, supra note 7; Harris, supra note 14; Waites, supra note 36.

41. Walsh, supra note 8. 
one case formed a suicide pact; ${ }^{42}$ a British Member of Parliament, while expressing concerns that proposed legal changes may be too vague and come too slowly, expressed hope that the controls may be implemented based on the moderate success of child pornography laws. ${ }^{43}$

A recent disturbing example of abuse of the wide open forum provided by suicide chat rooms is that of William Melchert-Dinkel, a nurse from Minnesota who appears to have encouraged multiple suicides through the medium, offering not only moral support but also medically-informed advice on the best way to accomplish suicide. ${ }^{44}$ Authorities in Minnesota, as well as Canada and the U.K, where two of Melchert-Dinkel's alleged victims resided and died, seem to believe that Melchert-Dinkel indeed encouraged and offered advice to his victims. No legal action was taken against Melchert-Dinkel until $2010,{ }^{45}$ though the deaths of his British and Canadian victims occurred in 2005 and 2008, respectively. While authorities abroad seem to have deferred to Minnesota prosecutors, ${ }^{46}$ those in charge of the domestic investigation proceeded only with extreme caution. ${ }^{47}$

Although originally American authorities seemed to struggle with issues of jurisdiction, proof, and constitutionality, ${ }^{48}$ prosecutors in Minnesota finally took up the case under the state's assisted suicide statute and charged Melchert-Dinkel on two counts, each carrying a maximum $\$ 30,000$ fine or 15 years imprisonment. ${ }^{49}$ Melchert-Dinkel pled not guilty to both counts, which pertain respectively to his victims in the United Kingdom in 2005 and Canada in 2008. ${ }^{50}$ Over Melchert-Dinkel's objection, the presiding judge held that Minnesota had jurisdiction even though the victims were non-Minnesotans who died abroad, because Melchert-Dinkel assisted suicides when he accessed

42. Eveleigh \& Carey, supra note 8 .

43. Id.

44. Emily Gurnon, Suspect Nurse Claimed an Addiction to Suicide, St. Paul Pioneer Press (Minn.), Oct. 14, 2009, at A1.

45. Gurnon, supra note 44; Walsh, supra note 8.

46. Lee Greenberg, Kajouji Case Goes to U.S. Prosecutor, Ottaw A Citizen (CAN.), Feb. 25, 2010 (describing "controversy" surrounding Canadian authorities' decision not to prosecute).

47. Walsh, supra note 8; see also Warren Manger, US Predator Quizzed over More Deaths, Coventry Telegraph (UK), Oct. 20, 2009, at 51.

48. McCoy, supra note 7.

49. Chris Williams, Associated Press, Nurse Charged with Aiding Suicide over Web, MSNBC.com, Apr. 23, 2010, available at http://www.msnbc.msn.com/id/36739748/ns/us_news-crime_and_courts (last accessed Jan. 27, 2011).

50. Aaron Rupar, Accused Suicide Nurse Pleads Not Guilty, OtTAwa Sun (CAN.), Dec. 20, 2010, available at http://www.ottawasun.com/news/ottawa/2010/11/19/16228461.html. 
the chat rooms from his Minnesota home. ${ }^{51}$ Perhaps more notably, the judge also rejected Melchert-Dinkel's free speech defense because Minnesota's "interest in protecting and preserving life is unrelated to suppressing free expression." 52

\section{The LAW of Cyber-Bullying}

\section{A. The Current State of the Law: Cyber-Bullying}

Because of the lack of legal precedent on the matter, "cyber-law" is, as one legislator has put it, "being developed by judges who must do their best to fit legal disputes into preexisting frameworks" with the result that "the legal principles governing conduct . . . in cyberspace are still in a state of flux." ${ }^{, 53}$ Nonetheless, efforts have been made. Currently at least forty-five states have amended their existing harassment laws to include cyber-bullying. ${ }^{54}$ However, many believe that the harassment statutes do not reach the heart of the issue of bullying, and some states and schools are attempting to enact policies such as education and disciplinary programs targeted at cyber-bullying. ${ }^{55}$

While legislative developments at the state level are in their infancy, judicial evaluations about the extent of students' First Amendment rights offer a bleak outlook for proponents of anti-cyber-bullying laws. In New Jersey in 2005 , a school district paid $\$ 117,500$ in settlement to a teen student after a federal District Court ruled that the school had violated the student's First Amendment rights by suspending him for creating a website criticizing the school and its faculty. ${ }^{56}$ That same year, a student's family won a $\$ 90,000$ settlement against a school district that had expelled the student for posting online rap songs that the school deemed threatening. ${ }^{57}$ In early 2010 , at least two more decisions in favor of students were issued. A Florida District Court declared that the First Amendment allowed a student to create a web page solely to criticize and "express hatred" of a teacher, ${ }^{58}$ while the Third Circuit

51. Lee Greenberg, Trial Date Set for Accused in Carleton Student's Suicide, Ottawa Citizen (CAN.), Dec. 21, 2010, at C4, available at http://www.ottawacitizen.com/news/Trial+date+accused+ Carleton+student+suicide/4006136/story.html.

52. Rupar, supra note 50.

53. McCoy, supra note 7.

54. Bauer, supra note 28.

55. Bauer, supra note 28.

56. Dwyer, No. 03-CV-6005 (D.N.J. 2005).

57. Latour, 2005 WL 2106562.

58. Evans v. Bayer, 684 F. Supp. 2d 1365 (S.D. Fla. 2010). 
likewise held that a student's creation of a fake profile to embarrass a school principle was constitutionally protected..$^{59}$

While these cases do not directly raise issues of student-to-student online bullying or suicide chat, they do suggest increasing judicial protection for student speech. Nonetheless, the federal government has shown signs of getting involved. The Megan Meier Cyberbullying Prevention Act, sponsored by House Representative Linda Sanchez, purports to make cyber-bullying a federal crime ${ }^{60}$ The bill was re-introduced in 2009 after it died in the House in 2008, but it is still plagued with possible constitutional problems ${ }^{61}{ }^{\text {The bill }}$ states:

(a) Whoever transmits in interstate or foreign commerce any communication, with the intent to coerce, intimidate, harass, or cause substantial emotional distress to a person, using electronic means to support severe, repeated, and hostile behavior, shall be fined .. or imprisoned not more than two years, or both. ${ }^{62}$

However, the bill's failure to define "emotional distress," "hostile," or "behavior," almost certainly renders it unconstitutionally overbroad in that the bill as written could prohibit a significant amount of protected speech. ${ }^{63}$ For any federal anti-cyber-bullying legislation to prevail, it will likely have to be narrower and better-defined than any version offered to date.

\section{B. First Amendment Protection for Bullies?}

There are two competing interests in the drive for legislation against cyber-bullying. The first is the usually very weighty individual interest, protected by the First Amendment, in free expression. ${ }^{64}$ The other is the government's interest in protecting children, who are legally recognized as an especially vulnerable group, ${ }^{65}$ from the psychological and physical harms, most prominently depression and suicide, which may result from cyberbullying. Although First Amendment protections are unquestionably important, the Supreme Court has previously recognized that the governmental

\footnotetext{
59. Layshock, 593 F.3d 249.

60. Rose, supra note 10.

61. Id.

62. John Cox, Bill Would Turn Internet Flamers into Felons, NETWORK WorLd, May 8, 2009, 2009

63. Cox, supra note 62; see also Ashcroft, 535 U.S. at 256 (finding a statute "overbroad and unconstitutional" because it abridged "freedom to engage in a substantial amount of lawful speech.").

64. Supra Part I.

65. Ferber, 458 U.S. 747.
} WLNR 8978200. 
interest in protecting children rises to the level of "compelling." ${ }^{66}$ Therefore, legislation narrowly tailored to serve that protective interest may be constitutional even if the law in question regulates speech based on its content. ${ }^{67}$

The general standard for regulating speech in the school setting was established by the Supreme Court in 1969, when the Court declared that school officials may suppress expression if they reasonably believe that the expression will "materially and substantially disrupt the work and discipline of the school." ${ }^{68}$ That standard has been applied in the context of online speech, which lower courts have generally held to be not sufficiently connected with actual events on campus to meet the test of material and substantial disruption. ${ }^{69}$ Lower court decisions preserving students' online speech rights reason that the connection between the speech in question and actual school activities is too attenuated and therefore does not implicate the "unique concerns" of the school environment that justify proscribing student speech. ${ }^{70}$

However, some lower court reasoning suggests that protection for student speech need not be so broad if, for example, off-campus speech falls into a category of speech traditionally recognized as outside of the First Amendment's protective ambit. ${ }^{71}$ A student's suspension for calling a teacher a "prick" in an off-campus parking lot was upheld on the grounds that the student had used "fighting words," "72 which the Supreme Court has declared to be categorically among the "well-defined . . classes of speech, the prevention and punishment of which have never been thought to raise any Constitutional problem." "73 Unprotected fighting words are "those which by their very utterance inflict injury." bullying falls squarely within this definition, and to that extent a school or even a legislative act could regulate cyber-bullying without running afoul of the First Amendment.

\footnotetext{
66. Id. at 756-57.

67. Perry Educ. Ass' $n, 460$ U.S. at 45 (holding that legislation affecting protected speech must pass strict scrutiny).

68. Tinker v. Des Moines Indep. Cmty. School Dist., 393 U.S. 503, 513 (1969).

69. Evans, 684 F. Supp. 2d at 1369.

70. Evans, 684 F. Supp. 2d at 1369; J.S. v. Bethlehem Area School Dist., 807 A.2d 847, 865 (Pa. 2002).

71. See Fenton v. Stear, 423 F. Supp. 767 (W.D. Pa. 1976).

72. Id. at 771

73. Chaplinsky, 315 U.S. at 571-72.

74. Id. at 572 .
} 


\section{Laws Against Encouraging Suicide}

\section{A. The Current State of the Law: Suicide Chat}

Thirty-nine states have statutes that make it a crime to assist suicide either generally, as part of a homicide statute or as a sui generis crime subject to mitigated penalties. ${ }^{75}$ Three other states have no statutory prohibition on assisting suicide but have common law equivalents dating as early as $1872 .{ }^{76}$ The United States Supreme Court, recognizing the importance of the underlying state policy of protecting human life, has consistently refused to strike down such statutes even against constitutional challenges brought by terminally ill patients seeking physician assistance in facilitating their deaths. ${ }^{77}$

Laws against assisted suicide are even more unequivocally upheld in a non-medical context. A New York court in 1992 upheld the manslaughter conviction of a defendant who provided a visibly distressed minor with both alcohol and a rifle and then told him to "put the gun in his mouth and blow his head off," finding that the defendant's reckless conduct resulted in the minor's suicide. ${ }^{78}$ In 1996, a Florida court upheld the validity of a prohibition on assisting self-murder in a case where a defendant gave a shotgun to a victim who had asked for the gun after indicating he wished to kill himself. ${ }^{79} \mathrm{~A}$ California court held in 2002 that there was sufficient evidence to charge a juvenile for attempting to assist a friend's suicide when that juvenile discussed methods of suicide with her, participated in purchasing the medicine on which she attempted to overdose and told her to be sure she took the medicine quickly so that it worked. ${ }^{80}$

There is very little precedent for prosecuting those who advocate and counsel suicide in online forums; problems of interstate and international jurisdiction, as well as of causation and proof, exacerbate the lack of clarity

75. In re Extradition of Exoo, 522 F. Supp. 2d 766, 779 (S.D. W. Va. 2007) (listing statutes).

76. Id. at 779-80.

77. See, e.g., Cruzan v. Director, Mo. Dept. of Health, 497 U.S. 261, 280 (1990) (acknowledging that "the majority of States in this country have laws imposing criminal penalties on one who assists another to commit suicide"); Vacco v. Quill, 521 U.S. 793, 808-09 (1997) (rejecting Fourteenth Amendment Equal Protection challenge).

78. People v. Duffy, 595 N.E. 2d 814, 815-17 (N.Y. 1992).

79. State v. Adams, 683 So. 2d 517, 518-20 (Fla. Dist. Ct. App. 1996).

80. In re Ryan N., 112 Cal. Rptr. 2d 620, 627, 640-41 (Cal. Ct. App. 2002). 
in this area of the law. ${ }^{81}$ The only United States case on point indicates, however, that there may be some basis in the criminal law not only for prosecuting but for convicting an individual like Melchert-Dinkel. In Oregon, a twenty-six year old man was charged with solicitation to commit murder after he arranged for a mass suicide pact through his website "Suicide Ideology," 82 and an Oregon jury found the defendant "guilty except for insanity." $" 83$

The case for prosecuting Melchert-Dinkel is even stronger than the Oregon solicitation case because unlike in that case, the targets of MelchertDinkel's illegal activity actually succeeded in committing suicide. This case is also similar to the New York and Florida cases above, in that MelchertDinkel gave verbal encouragement to vulnerable victims who did in fact commit suicide. Indeed, Melchert-Dinkel arguably did more than just encourage because he used his training as a nurse to offer detailed, medically accurate advice on the most effective way to commit suicide, even going so far as to tell one woman the exact kind of rope with which she should hang herself. $^{84}$

\section{B. First Amendment Protection for Encouraging Suicide?}

Because the First Amendment is seen as a cornerstone of our democratic society, First Amendment protection of speech of little or even no value is well-accepted in American legal discourse. ${ }^{85}$ However, one of the most obvious exceptions to these expansive protections is that the government may legitimately proscribe words that inflict injury or may cause a breach of the peace. ${ }^{86}$ The Supreme Court has declared that such words provide "no essential part of any exposition of ideas, and are of such slight social value that any benefit that may be derived from them is clearly outweighed by the social interest in order and morality." ${ }^{\prime 77}$

81. Anderssen, supra note 7 ("In Canada, as in most countries [including the U.S.], it is illegal to counsel someone to commit suicide, although the law has yet to be tested in cases involving anonymous online interaction"); Gurnon, supra note 44 (trying to identify victims and causation in case of man accused of encouraging suicide in suicide chat rooms is "tedious and sensitive ... [i]n some cases, they have to determine whether or not there was a successful suicide.").

82. US Web Suicide Suspect, supra note 8.

83. Krein, 188 P.3d at 467 (rev'd on other grounds).

84. Gurnon, supra note 44.

85. Playboy Ent'mt Group, 529 U.S. at 826.

86. Chaplinsky, 315 U.S. at 572.

87. Id. 
Words encouraging vulnerable people to take their own lives when those people seek guidance, egging on a young man to overdose on live video or exchanging tips on the most effective method to kill oneself almost certainly fall within this category. Ordinarily benign words spoken in encouragement of suicidal tendencies and counseling on the science of taking one's own life certainly inflict injury. Moreover, a suicide pact or an online community that assembles to watch one man die by his own hand without attempting to stop it seems clearly to threaten social order and morality. Such words may not be what the Supreme Court had in mind when it spoke in 1942 of "slight social value," but they are only an "essential part of any exposition of ideas" to the extent that the ideas they foster are harmful in the gravest sense. Thus, speech in suicide chat rooms is unprotected at a minimum where it effectively encourages a fellow user's suicidal behavior.

Even if suicide chat were protected by the definition above, it may still be unprotected in the forty-two states where assisting a suicide is a crime. ${ }^{88}$ The Supreme Court has excluded from the First Amendment's protection speech that is directed to producing and likely to result in imminent unlawful action. ${ }^{89}$ This may be so even though suicide itself is no longer a crime in any state. ${ }^{90}$ Speech encouraging suicide in the context of a suicide chat room, where the likelihood of actual harm is much higher than if the speech were indiscriminately addressed to any individual, may itself suffice as the unlawful act of assisting suicide because such speech in those circumstances is directed to and more likely to encourage another to take his or her own life. Punishing such speech serves the compelling policies of "discourag[ing] those who might encourage a suicide to advance personal motives," 91 preserving the sanctity of life, ${ }^{92}$ and the special concern that "although the suicide victim may be mentally ill in wishing his [or her] demise, the aider is not necessarily mentally ill." ${ }^{93}$ Those policies would undoubtedly be furthered by ensuring justice for victims of individuals like Melchert-Dinkel, who prey on people reaching out for help in a time of vulnerability.

88. See Part IV A, supra.

89. Brandenburg v. Ohio, 395 U.S. 444, 447 (1969).

90. In re Joseph G., 667 P.2d 1176, 1178 (Cal. 1983) ("[N]o state . . . has a statute making successful suicide a crime, nor does the Model Penal Code recognize suicide as a crime") (citations omitted).

91. Ryan N., 112 Cal. Rptr. 3d at 631 (citations omitted).

92. Id. (citations omitted); Cruzan, 497 U.S. at 280; Vacco, 521 U.S. at 798.

93. Ryan N., 112 Cal. Rptr. 3d at 631 (citations omitted) (brackets in original). 


\section{Possible Solutions}

\section{A. Public}

As previously discussed, there are many difficulties with regulating speech over the Internet, and there is no easy or obvious solution. The history of First Amendment law shows that American jurisprudence will not permit general bans on almost any public discussion, because such broad prohibitions on the free exchange of ideas are the very evil against which the First Amendment protects..$^{94}$ Moreover, given the vast array of possibilities for any person with Internet access to express himself or herself, the definitions contained in a statute aimed at regulating Internet speech would have to be very precise, and it is not yet clear that such precision can be achieved. ${ }^{95}$

Nonetheless, other countries have tried. As mentioned above, laws passed in Australia and Japan banning suicide websites have been largely unsuccessful. ${ }^{96}$ A British Medical Journal study may explain why; the study suggests that people who randomly search the Internet for information about suicide most frequently land on sites telling them how to do it, rather than how to get help. ${ }^{97}$ The British Suicide Act has had a similarly limited effect, because under that Act only people who have actually met with victims outside of the Internet context are held legally accountable for helping the victims to die. ${ }^{98}$

Perhaps more promising, the British Criminal Attempts Act states that websites that "intentionally encourage suicide" and can be linked to an actual or attempted suicide may be prosecuted. ${ }^{99}$ Similarly, the European Union, which funds the online regulatory body Internet Watch Foundation, has stipulated that "any person making a posting to a suicide chat room which intentionally encourages another person to commit or attempt to commit

94. Abrams, 250 U.S. at 630; De Jonge, 299 U.S. at 364.

95. Rose, supra note 10 (providing opinion of First Amendment scholar that current federal anticyber-bullying legislation is impermissibly vague and, if passed, it would be struck down in courts as unconstitutional); Goodale, supra note 32 ("If Congress wants to stop dangerous cyber-bullies, it has to say so," suggesting Congress should follow the model of the states that have amended their harassment laws to include cyber-bullying); Cox, supra note 62 ("Given the free-wheeling exchanges that characterize everything from ... instant messaging, to blogs and Web site comments, the broadly written [federal anticyber-bullying] bill potentially could turn a lot of flamers and bloggers into felons").

96. Anderssen, supra note 7.

97. Id.

98. Eveleigh \& Carey, supra note 8.

99. Harris, supra note 14 . 
suicide may be guilty of an offence." ${ }^{100}$ However, both the British Act and the Foundation's policy are fraught with possibilities rather than actualities, and in practice prove difficult to enforce. ${ }^{101}$ This is somewhat unsurprising given the vastness and anonymity associated with the Internet, both of which cause major glitches to any successful efforts to police online activity. ${ }^{102}$ In sum, because of the Internet's broad reach to billions of people in nearly every corner of the globe, even without free speech considerations governmental regulation of the Internet still poses massive challenges jurisdictionally, technologically and practically.

\section{B. Private}

In light of the multitude of problems associated with successful government regulation of harmful Internet speech without infringing on protected expression, a more viable option may be to leave the regulating to non-government sources. For example, it is possible to block cyber-bullying messages through an Internet service provider, social network site or chat room moderator; ${ }^{103}$ a survey indicated that almost two-thirds of teens, who are most likely to be both victims and perpetrators of cyber-bullying, believe this to be the most effective way to prevent cyber-bullying. ${ }^{104}$ Some cyber-bullying experts agree that " $[\mathrm{t}]$ he vast majority of all cyber-bullying can be handled informally - by parents, educators, or other community members" before the activity becomes too serious. ${ }^{105}$

The idea of privately blocking connections with certain sites may be helpful in the context of suicide chats as well. For example, the Supreme Court has held that a private citizen might constitutionally have the postal service block some mail. ${ }^{106}$ Translated to the domain of the Internet, it seems logical that an individual may choose to block access to certain sites he or she perceives as harmful. However, a lonely or despondent person seeking counsel in a time of deepest depression may not want to block the site, and therefore the potential harm may not be completely averted simply by voluntarily opting out of certain Internet access.

100. Id.

101. $I d$.

102. Anderssen, supra note 7.

103. Bauer, supra note 28.

104. Id.

105. Cox, supra note 62.

106. Rowan v. United States Post Office Dept., 397 U.S. 728 (1970). 
Ironically, one of the most widespread models of self-regulation by nongovernment bodies is the much-maligned Chinese system of "selfdiscipline." 107 That system is an extreme version of intermediary liability in which the service that transmits or publishes information is liable for its user's activities. ${ }^{108}$ Under the Chinese system, companies that fail to track and remove content or to block conversations prohibited by regulators face penalties ranging from a fairly severe fine to being permanently shut down. ${ }^{109}$

While this system is understandably rejected in the United States and in other nations where the free exchange of ideas is one of the foundational principles of society, the idea of holding private carriers and servers legally responsible for their customers' activities is increasingly attractive to some as a simple and inexpensive solution to the ever-growing list of problems posed by new media, including cyber-bulling and harmful speech. ${ }^{110}$ In fact, France, Italy and the U.K. are all considering the idea, and some reports not yet made public indicate that the Obama administration is negotiating an international trade agreement that would include a term increasing the liability of "content hosting companies and service providers," with the purported goal of reducing Internet piracy of movies and music. ${ }^{11}$

\section{CONCLUSION}

Overall, there is no easy solution to the unique problems posed by harmful speech on the Internet. Certainly the United States government, as well as the governments of individual states, should not have the unqualified ability to tell private citizens what they may say in the sanctity of their own homes. However, problems arise when speech technically executed in private is projected to the public through the powerful and widespread medium of the Internet. That speech is no longer purely private, and yet still retains much of the protection afforded to individual expression. Therefore, when speech on the Internet causes harm, potential difficulties arise both in terms of locating the appropriate jurisdiction and in terms of causation.

With cyber-bullying, the inquiry is how much harm was caused, and what kind. Most, if not all, children at some point get teased and insulted by their

107. Is the West Following China in Policing?, New India Express (InDIA), Jan. 22, 2010, 2010 WLNR 1363646.

108. Id.

109. $I d$.

110. $I d$.

111. Id. 
peers, but not all commit suicide. When the Internet comes into play, however, the teasing leaves the playground and follows the child home; it takes on a life of its own as it grows and spreads over the Internet. It is not clear, however, at what point that happens, and it is therefore very difficult to properly tailor legislation that would not encompass significant protected speech. Similarly, a blanket ban on suicide chat rooms is not only inconsistent with First Amendment law, but may not be desirable. Surely not all content on websites containing information about suicide is harmful, and some may even be helpful. Again, the problem becomes one of line-drawing, and it is not entirely clear where harmful content outweighs helpful, or where the causal link between being suicidal and being encouraged to commit suicide is, if ever, present.

Despite these difficulties, harm is done by cyber-bullying and suicide chat rooms. Children do not want to go to school because they are incessantly harassed by their peers, and young people are not only finding it easier to kill themselves but also finding the moral support they crave at exactly the wrong time. These harms are real, but many do not consider them so common as to be considered a major public health risk. Ultimately the answer may be as simple as better education about the dangers of harmful speech, in which case the Internet itself may be the best jumping-off point. Rather than banning content, perhaps require that certain sites more prone to cyber-bully or prosuicide activity prominently post educational material on how to deal with the evils sought to be avoided. Additional materials should certainly be available to those who seek them, and whether those materials come from private sources or the government is relatively unimportant as long as awareness is raised. Whatever the answer, those affected need and deserve a solution that has yet to be devised. 